\title{
Laboratory experiments examining inducible defense show variable responses of temperate brown and red macroalgae
}

\author{
Experimentos de laboratorio para examinar las defensas inducibles muestran respuestas \\ variables en macroalgas pardas y rojas de ambientes templados \\ EVA ROTHÄUSLER ${ }^{1}$, ERASMO C. MACAYA ${ }^{2}$, MARKUS MOLIS ${ }^{3,4}$, \\ MARTIN WAHL ${ }^{3} \&$ MARTIN THIEL $^{2 *}$ \\ ${ }^{1}$ Institute of Aquatic Ecology, Albert-Einstein-Str.3, 18057 Rostock, Germany \\ ${ }^{2}$ Departamento de Biología Marina, Facultad de Ciencias del Mar, \\ Universidad Católica del Norte, Larrondo 1281, Coquimbo, Chile \\ ${ }^{3}$ Leibniz Institute of Marine Sciences, Marine Ecology-Marine Zoology, \\ Düsternbrooker Weg 20, 24105 Kiel, Germany \\ ${ }^{4}$ Marine Biological Station Helgoland, Foundation Alfred Wegener \\ Institute for Polar and Marine Research, Kurpromenade 201, 27498 Helgoland, Germany \\ * Corresponding author: e-mail: thiel@ucn.cl
}

\begin{abstract}
Macroalgae can defend themselves against generalist and specialist herbivores via morphological and/or chemical traits. Herein we examined the defensive responses (via relative palatability) of two brown (Lessonia nigrescens, Glossophora kunthii) and two red algae (Grateloupia doryphora, Chondracanthus chamissoi) from the northern-central coast of Chile against selected generalist meso-herbivores. Two laboratory experiments were conducted to investigate whether (i) algae can respond generally to grazing pressure of meso-herbivores (amphipods, isopods and juvenile sea urchins) and whether (ii) these algal responses were inducible. In order to examine palatability and thus effectiveness of responses, feeding assays were run after each experiment using fresh algal pieces and artificial agar-based food. Lessonia nigrescens responded to amphipods but not to sea urchins, and G. kunthii showed inducible response against one species of amphipods. Grateloupia doryphora did not respond against any of the tested grazers, whereas $C$. chamissoi responded against one species of amphipods and the tested isopod. Our results indicate variable responses of macroalgae against selected generalist meso-herbivores and evidence of an inducible defense in the brown alga G. kunthii.
\end{abstract}

Key words: palatability, defense, meso-herbivores, macroalgae.

\section{RESUMEN}

Muchas macroalgas poseen la capacidad de defenderse contra herbívoros generalistas y especialistas utilizando defensas químicas y/o morfológicas. En este trabajo se examinó la respuesta de la palatabilidad ante meso-herbívoros generalistas de dos algas pardas (Lessonia nigrescens, Glossophora kunthii) y dos algas rojas (Grateloupia doryphora, Chondracanthus chamissoi) de la costa Norte de Chile. Se realizaron dos experimentos de laboratorio para investigar si: (i) las algas pueden responder al pastoreo realizado por meso-herbivoros generalistas (anfípodos, isópodos y erizos juveniles) y (ii) si la respuesta de estas algas es inducible. Para examinar la palatabilidad y de esta forma la efectividad en las respuestas, se realizaron pruebas de alimentación luego de cada experimento, utilizando para ello algas frescas y alimento artificial. Lessonia nigrescens respondió a los anfípodos pero no así a los erizos. Sin embargo, G. kunthii mostró respuestas inducibles frente a una especie de anfípodo. Grateloupia doryphora no presentó respuestas frente a ninguno de los herbívoros, mientras que $C$. chamissoi lo hizo frente a una especie de anfípodo e isópodo. Nuestros resultados indican respuestas variables de las macroalgas contra los meso-herbívoros seleccionados y evidencian una respuesta inducible por parte del alga parda G. kunthii.

Palabras clave: palatabilidad, defensas, meso-herbívoros, macroalgas. 


\section{INTRODUCTION}

Marine macroalgae are subject to attack by generalist and specialist herbivores. Depending on the capability of algae to resist herbivory and on the food preferences of grazing species, herbivory can strongly influence macrophytobenthic species composition, in both temperate and tropical shallow waters (Lubchenco \& Gaines 1981, Carpenter 1986, Van Alstyne 1989). A wide variety of macroalgae are often consumed with a ranked order of preference by large mobile generalist herbivores such as fishes, sea urchins and gastropods (Lubchenco \& Gaines 1981). A few types of algae and algal tissues are consumed by specialist herbivores (e.g. ascoglossan gastropods, tube-building amphipods), but these specialists are considered to be rare in marine systems (Hay \& Fenical 1988, Hay et al. 1989) as opposed to terrestrial communities.

Macroalgae can persist by avoiding (temporally and spatially), tolerating or deterring herbivores (Lubchenco \& Gaines 1981, Duffy \& Hay 2001). However, defensive mechanisms might be expensive to produce and maintain (Baldwin 1998) if they use up resources that could have been allocated to growth or reproduction (Herms \& Mattson 1992). Defenses can be either morphological or chemical. Morphological defenses are structural features that reduce the susceptibility to grazers, e.g. tissue toughness (Watson \& Norton 1985), adventitious branches (Van Alstyne 1989) or calcification of structures (Paul \& Hay 1986). In contrast, chemical defenses are based on the production of chemical components that can serve as deterrents against consumers (Hay \& Fenical 1988, Hay \& Steinberg 1992), i.e., a degradation in algal palatability. Chemical deterrents often comprise secondary metabolites, which are constantly produced (constitutive defense) or induced upon e.g., grazer attacks (inducible defense) or due to changes in the environment (Karban \& Baldwin 1997).

Induced defenses are triggered by injury and result in increased protection from potential grazers by reducing algal palatability (Paul \& Van Alstyne 1992). In contrast, when algae have constitutive defense, the chemical deterrents are maintained constantly, even when consumers are absent and protection offers no benefits (Cronin \& Hay 1996a). Constitutive defense is thought to be most effective in deterring large herbivores such as fishes and sea urchins that are highly mobile and can destroy entire plants in minutes to hours (Hay 1996). In contrast, feeding by meso-grazers (e.g. isopods and amphipods) rather than by fishes and urchins may induce defenses in seaweeds because they operate over spatial and temporal (i.e., hours to days) scales that would allow induced chemical responses to become effective (Hay 1996). Algae that produce repulsive traits only in case of need might be able to reduce costs by allocating resources to growth and reproduction when they are not under attack by herbivores (Clark \& Harvell 1992).

The majority of inducible defenses have been reported for brown macroalgae (e.g., Rhode et al. 2004), while few examples exist for red macroalgae (e.g., Weidner et al. 2004). Despite having deterrent secondary metabolites (e.g., Paul \& Van Alstyne 1987, Hay \& Fenical 1988), so far no examples of induced defenses have been reported from green algae. To date, most studies tested an induction of chemical defenses by using single species of herbivores and not against a diverse array (e.g., Cronin \& Hay 1996a, Sotka et al. 2002, Taylor et al. 2002, Toth \& Pavia 2002). In an earlier study we revealed that the brown alga Glossophora kunthii induced defenses when grazed by a generalist amphipod grazer (Macaya et al. 2005). However, this alga may respond differently when attacked by macro- or other meso-herbivores. Analogously, the same generalist amphipod grazer that provoked inducible defense in G. kunthii may cause a different reaction in other alga species. Understanding the relationship between deterrents and grazers appears important since the effects of deterrents may vary between different grazers (Pavia \& Toth 2000, Amsler 2001). Herein we examined the question whether grazing by generalist amphipods, isopods and juvenile sea urchins can reduce the palatability and thus increase the defensive reactions of two red and two brown algae from the temperate SE-Pacific. 


\section{MATERIAL AND METHODS}

\section{Sampling sites and organisms}

Two laboratory experiments, hereafter termed "exploratory induction experiment EXPIN" and "acclimation-induction-recovery experiment AIR" were performed during austral spring and fall 2003 in an outdoor laboratory at Universidad Católica del Norte, Coquimbo, Chile. Algae were collected in coastal habitats in the vicinity of Coquimbo $\left(29^{\circ} 55^{\prime} \mathrm{S}, 71^{\circ} 20^{\prime}\right.$ $\mathrm{W})$. Both brown algae, Lessonia nigrescens (Bory 1826) and Glossophora kunthii (C. Agardh) J. Agardh 1822 were sampled in the intertidal, while the red algae Chondracanthus chamissoi (C. Agardh) Kützing, 1843 and Grateloupia doryphora (Montagne) Howe 1914 were collected in the subtidal zone (5-6 m depth).

The generalist meso-grazers used were the amphipods Parhyalella ruffoi (Lazo \& Wamble 2001) and Hyale hirtipalma (Dana 1852), the isopod Isocladus bahamondei (Carvacho 1997) and juvenile individuals of the sea urchin Tetrapygus niger (Molina 1782). The amphipod species $P$. ruffoi and the isopod I. bahamondei were collected from mixed assemblages of subtidal drift algae (e.g., Ulva spp., L. nigrescens, G. doryphora, C. chamissoi) at the sheltered beach Playa Guayacán (2958' S, $\left.71^{\circ} 21^{\prime} \mathrm{W}\right)$. Hyale hirtipalma was collected from the intertidal zone of the exposed shore La Pampilla (29 $\left.57^{\prime} \mathrm{S}, 71^{\circ} 21^{\prime} \mathrm{W}\right)$ where it feeds on a variety of attached red, green and brown algae. Juvenile individuals of Tetrapygus niger were sampled from rock pools at La Pampilla.

The densities of grazers used herein for both experiments, were chosen based on preliminary feeding assays that showed that grazers consumed measurable amounts of biomass from each algal species without causing grazingrelated decay of algae. Furthermore, similar densities of meso-grazers had been used in comparable studies of inducible defenses (Sotka et al. 2002, Taylor et al. 2002, Weidner et al. 2004).

\section{General experimental set-up}

Both, the EXPIN- and the AIR-experiment were set up in an outdoor flow-through aquaria system. Filtered seawater (10 $\mu \mathrm{m}$ cotton cartridge) was pumped from the shallow subtidal zone of Bahía La Herradura into four plastic reservoirs (70 L), supplying each experimental aquarium $(10$ x $19 \times 13 \mathrm{~cm}, 1.5 \mathrm{~L}$ volume) via flow-regulated pipes individually at a rate of $0.1 \mathrm{~L} \mathrm{~h}^{-1}$ with seawater. The aquaria were additionally maintained with continuous aeration.

\section{Exploratory induction EXPIN experiment}

The objective of the EXPIN experiment was to learn whether and which temperate macroalgae respond with deterrents against grazing by different generalist meso-herbivores. The experiment was conducted in December 2003 with blades (containing growth meristem) of $L$. nigrescens and whole plants of G. kunthii, G. doryphora and $C$. chamissoi. Each algal species was represented with 12 experimental aquaria, containing one piece of the respective alga. For each brown and red algal species we conducted parallel experiments with two different grazer species, each combination with three replicates of a 'Control Treatment' and a 'Grazing Treatment'. In the 'Control Treatment', test algae were kept grazer-free, while in the 'Grazing Treatment' herbivores were added to test whether algae can respond with production of deterrents.

The brown algae, L. nigrescens and $G$. kunthii, were tested for production of deterrents in the 'Grazing Treatment' with six individuals of $H$. hirtipalma (size $\approx 8 \mathrm{~mm}$ ) and with two individuals of $T$. niger (test diameter $\approx 15 \mathrm{~mm}$ ), while the red algae $G$. doryphora and $C$. chamissoi were tested with six individuals of $I$. bahamondei $($ size $\approx 6 \mathrm{~mm}$ ) and six individuals of $H$. hirtipalma (size $\approx 8 \mathrm{~mm}$ ). The experiment lasted 14 days. In order to reveal differences in algal palatability between control and grazerexposed specimens, feeding assays were conducted using fresh individuals of the respective grazers (see details below).

We selected $H$. hirtipalma for this experiment, because it is a very common grazer along the Chilean coast, and we wanted to use at least one grazer species for all tested algae species. Sea urchins and isopods were used because they occur abundantly in the respective habitats of the algae, where they have been observed to feed on the tested algae species. 
Acclimation-Induction-Recovery AIR experiment:

In order to examine whether grazing by the amphipod $P$. ruffoi can induce a decrease in algal palatability, blades of L. nigrescens and whole plants of G. kunthii, C. chamissoi and $G$. doryphora were collected in May 2003. A total of 160 algae were distributed over 40 experimental aquaria. Each species was represented with 10 aquaria and each of them received in the case of $G$. kunthii, $C$. chamissoi and $G$. doryphora four whole individuals and in the case of L. nigrescens four blades, of the same species.

The AIR experiment was divided into an acclimation-, induction- and recovery phase, each lasting 12 days. With the acclimation phase we checked whether defenses in the algal species had already been induced in the field, i.e. due to exposure to natural grazing regimes. Thus, immediately after collection five extra pieces of each species were deepfrozen at $-40{ }^{\circ} \mathrm{C}$ in order to present the 'Natural' level of defense. Additionally, each algal species was maintained during the acclimation phase in five extra aquaria, each containing one algal piece of the respective species. After the acclimation phase, the five algae from the extra aquaria, which represented now the 'Control' level, were deep-frozen for two days. All frozen algal pieces were later compared in a feeding assay with artificial agar-based food (see below).

In the following induction phase we examined whether grazing by $P$. ruffoi $(\approx 8 \mathrm{~mm}$ length) decreased algal palatability relative to control plants. In one half of the aquaria $(n=5)$ 15 individuals of $P$. ruffoi were added, representing the 'Grazing Treatments' and the remaining half $(\mathrm{n}=5)$ were kept without grazers to serve as 'Control Treatments'. After the induction phase, two algal pieces were taken from each aquarium for feeding assays with artificial agar-based and live algal food.

In the recovery phase we examined whether, in the case of an induction, palatability of algae increased again after grazing had stopped. Therefore all amphipods were removed from the set-up at the beginning of the recovery phase. At the end of the recovery phase, the remaining two algal pieces from each aquarium were used for the feeding assays.
After each experimental phase, we conducted no-choice feeding assays with artificial agar-based food and additionally after the induction and recovery phase with live algae using the amphipod $P$. ruffoi, in order to test for changes in palatability of the different treated algae (details about assays see below).

General design of the feeding assays to examine algal palatability

The aim of feeding assays after the two experiments was to examine whether consumption rates were different between control and grazer-exposed algae. Significantly higher consumption rates on live control algae compared to grazer-exposed algae would indicate morphological and/or chemical defenses, while the same result for agar-based food confines anti-herbivore defenses to nonpolar algal compounds.

In the EXPIN experiment, no-choice feeding assays were only conducted with live algae $(n=3)$. A single small algal piece $(\approx 0.38$ g) was cut out from the centre of each blade, weighed, offered to grazers in a Petri dish (diameter $\approx 8.8 \mathrm{~cm}$, volume $\approx 30 \mathrm{~mL}$ ) for 2 days at $15^{\circ} \mathrm{C}( \pm 1 \mathrm{SD})$ and a $12 \mathrm{~h}$ photoperiod of $40 \pm 10 \mu \mathrm{mol} \mathrm{m} \mathrm{m}^{-2} \mathrm{~s}^{-1}$ (fluorescent lamp, 40 W, Phillips, Brazil) and was reweighed at the end of the feeding assay. Algal wet mass was determined to the nearest $\mathrm{mg}$, using an analytical balance (Denver Instrument $100 \mathrm{~A} \pm$ $0.2 \mathrm{mg}$ ) after blotting algae for $30 \mathrm{sec}$ with absorbent paper to remove excess water. Consumption rates were calculated as the difference between initial and final algal wet mass. Different grazer individuals were used between the experiment and feeding assays. Grazer densities in feeding assays were six individuals of $H$. hirtipalma (all algae), one individual of $T$. niger (brown algae) and six individuals of I. bahamondei (red algae).

In the AIR experiment we could conduct only assays with artificial agar-based food after the acclimation phase, because algae were killed during defrosting. After the induction and recovery phase, we conducted assays $(n=$ 5) with both artificial agar-based food and live algae.

After the acclimation phase we made artificial agar-based food from the frozen algal pieces in order to test for the palatability of 
algae with 'Natural' level of defense and those of the 'Control' level. After the induction phase amphipods $P$. ruffoi were offered a previously grazed alga or a control alga. In the following recovery phase the amphipods were offered control algae and algae that were held for 12 days without grazers and thus could have lost defense again. Feeding assays for artificial agar-based food were conducted in petri-dishes (diameter $\approx 8.8 \mathrm{~cm}$, volume $\approx 30 \mathrm{~mL}$ ) with four amphipods of $P$. ruffoi, while those with entire live algae were done in transparent plastic containers (volume $\approx 1 \mathrm{~L}$ ) with a density of 20 P. ruffoi.

As a response variable for an assessment of palatability during the feeding assays, we used for live algal pieces the amount of algal tissue consumed, and for artificial agar-based food the number of squares consumed (see next subsection for details).

Preparation of artificial agar-based food containing non-polar extracts

At the end of each phase one algal piece from each experimental aquarium $(\mathrm{n}=40)$ was placed separately in plastic containers filled with Dichloromethane (DCM) for the extraction of a lipophilic crude extract. The extraction lasted for $48 \mathrm{~h}$ (Hay et al. 1994) at a 1:2 ratio (1 g algal wet mass: $2 \mathrm{~mL}$ DCM). DCM extracts only the lipophilic compounds, and thus any non-lipophilic compounds, which might also contain feeding deterrents, are disregarded by this procedure. The lipophilic extract was dropped on freeze-dried and finely powdered Ulva lactuca. To determine the amount of Ulva powder for every sample, algae were weighed before adding DCM. A ratio 3:1 (alga wet weight: dried Ulva powder) was used in order to obtain approximately similar proportions between the dried powder and the wet mass of the algae. After evaporation of the lipophilic extract, $8 \mathrm{~mL}$ distilled water was added to the Ulva powder. Ten $\mathrm{mL}$ distilled water were mixed with $0.36 \mathrm{~g}$ agar, boiled in a microwave and, after the agar cooled down to $40{ }^{\circ} \mathrm{C}$, added to the Ulva powder coated with the lipophilic algal crude extract. The agar/ Ulva mixture was poured into a mold laid over a fly mesh (mesh size $1 \mathrm{~mm}^{2}$ ) and 200 squares were cut out after hardening. Consumption rates of this agar-based food were determined by counting with a dissecting microscope the empty (= eaten) mesh squares $\left(1 \mathrm{~mm}^{-2}\right.$ surface area each) after each feeding assay.

\section{Statistical analysis}

Prior to the statistical analyses, all data were tested for homogeneity of variances with the Cochran's test (Underwood 1997). Results of the no-choice feeding assays for both experiments were analyzed with a t-test for independent samples.

\section{RESULTS}

\section{Exploratory induction EXPIN experiment}

At the end of the EXPIN experiment, significant differences in consumption rates between control and grazer-exposed algae were observed in two of the four tested species of algae (Fig. 1). Grazing by amphipods significantly reduced palatability of $L$. nigrescens relative to that of ungrazed conspecifics (Student t-test for independent samples, $\mathrm{t}=-2.89$, df $=4, \mathrm{P}=0.044)$. In contrast, consumption rates of sea urchins on this alga were not significantly different to control algae (Student t-test for independent samples, $\mathrm{t}=0.50, \mathrm{df}=4, \mathrm{P}=0.645$ ). For the second brown alga, G. kunthii, no feeding preferences were found between control algae and conspecifics exposed to either $H$. hirtipalma (Student t-test for independent samples, $\mathrm{t}=-0.72$, $\mathrm{df}=4, \mathrm{P}=0.512$ ) or $T$. niger (Student $\mathrm{t}$-test for independent samples, $\mathrm{t}$ $=-0.07, \mathrm{df}=4, \mathrm{P}=0.944)$.

Ungrazed individuals of the red alga $C$. chamissoi were significantly more consumed by Hyale hirtipalma (Student t-test for independent samples, $\mathrm{t}=-4.56$, $\mathrm{df}=4, \mathrm{P}=$ 0.010 ) and I. bahamondei (Student t-test for independent samples, $\mathrm{t}=-3.84$, df $=4, \mathrm{P}=$ 0.018) compared to grazer-exposed conspecifics. Neither isopods (Student t-test for independent samples, $\mathrm{t}=0.64$, $\mathrm{df}=4, \mathrm{P}=$ 0.952), nor amphipods (Student t-test for independent samples, $\mathrm{t}=-0.35$, df $=4, \mathrm{P}=$ 0.742) caused significant differences in consumption rates between grazed and ungrazed algae of $G$. doryophora, the second red alga tested. 

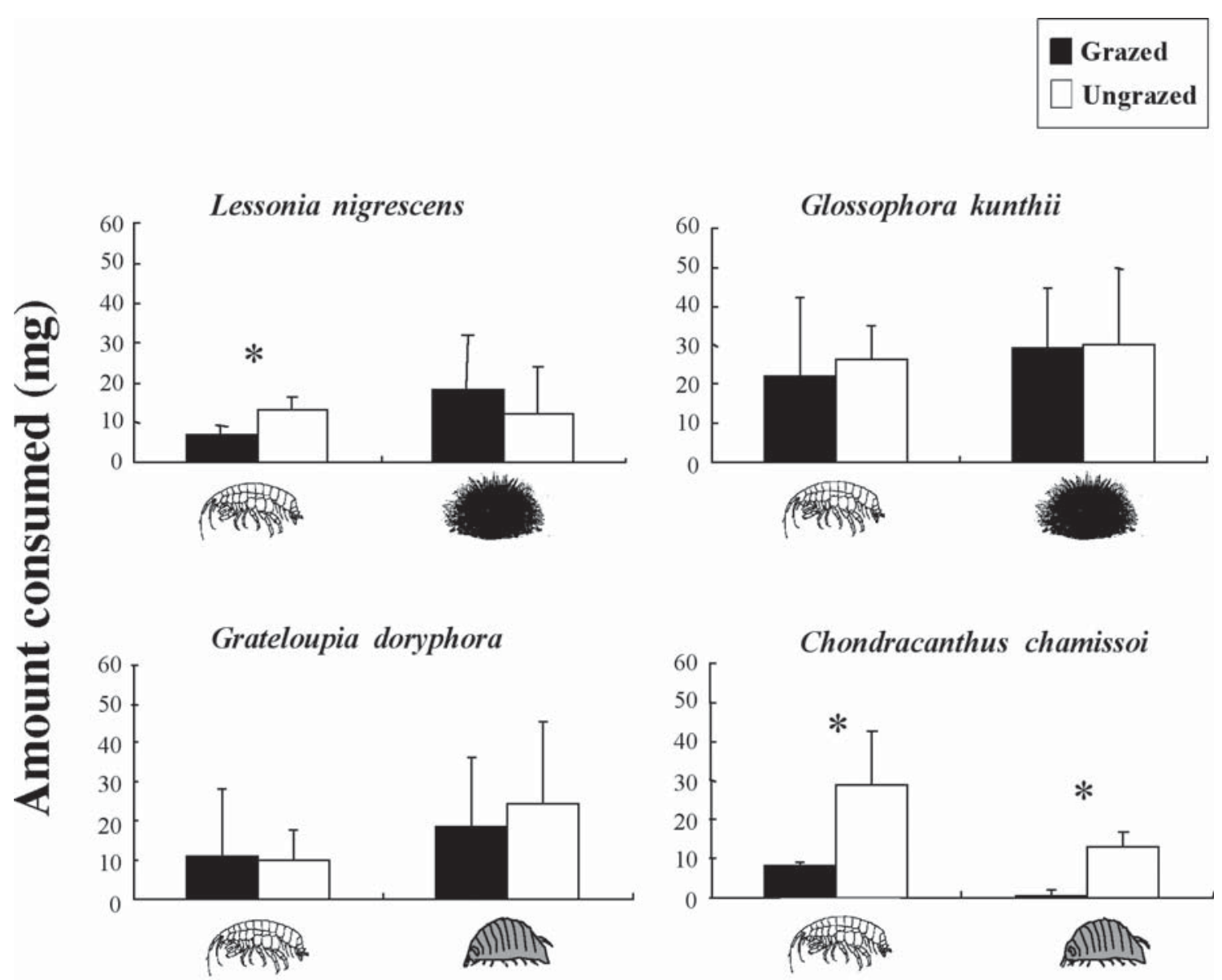

Fig. 1: Exploratory induction EXPIN experiment: mean ( $\pm \mathrm{SD})$ consumption $(\mathrm{mg})$ of grazer exposed and ungrazed control pieces of Lessonia nigrescens and Glossophora kunthii by the amphipod Hyale hirtipalma and the sea urchin Tetrapygus niger and of Grateloupia doryphora and Chondracanthus chamissoi by Hyale hirtipalma and the isopod Isocladus bahamondei; $\mathrm{n}=3,(*)=\mathrm{P}<0.05$. The same species of mesograzers were used in experimental treatments and feeding assays, but fresh individuals were used in feeding assays.

Experimento de inducción exploratorio EXPIN: media $( \pm \mathrm{DE})$ del consumo $(\mathrm{mg})$ en trozos expuestos a herbivoría y trozos controles sin herbivoría de Lessonia nigrescens y Glossophora kunthii por el anfípodo Hyale hirtipalma y el erizo Tetrapygus niger y de Grateloupia doryphora y Chondracanthus chamissoi por Hyale hirtipalma e Isocladus bahamondei; $\mathrm{n}=3$, $(*)=\mathrm{P}<0,05$. Las especies de meso-herbívoros usados en el tratamiento experimental y pruebas de alimentación fueron las mismas, pero nuevos individuos fueron utilizados para las pruebas de alimentación.

\section{Acclimation-induction-recovery AIR experiment}

At the end of the acclimation phase (Fig. 2), amphipods significantly preferred acclimated over field-collected pieces of $L$. nigrescens (Student $\mathrm{t}$-test for independent samples, $\mathrm{t}=$ 2.341, $\mathrm{df}=4, \mathrm{P}=0.047$ ) and $G$. kunthii (Student t-test for independent samples, $\mathrm{t}=$ 3.189 , df $=4, P=0.013)$. No significant differences were observed between acclimated and field-collected individuals of red algae, $C$. chamissoi (Student t-test for independent samples, $\mathrm{t}=2.24, \mathrm{df}=8, \mathrm{P}=0.055)$ and $G$. doryophora (Student t-test for independent samples, $\mathrm{t}=-0.334, \mathrm{df}=8, \mathrm{P}=0.747$ ).

Amphipods showed no significant differences in consumption rates between grazer-exposed and control pieces of agar-based food containing non-polar extracts (Fig. 2, Table 1). Palatability levels of live brown algae were significantly affected by grazers (Fig. 3). Exposure to amphipods significantly enhanced palatability of L. nigrescens, relative to control pieces (Student $\mathrm{t}$-test independent samples, $\mathrm{t}=$ 
2.776, df $=4, \mathrm{P}=0.024)$. The opposite was observed for $G$. kunthii (Student t-test independent samples, $\mathrm{t}=3.475$, df $=4, \mathrm{P}=$ 0.008). Consumption rates of both red alga species were not significantly different between grazed and control individuals (Fig. 3, Table 1). At the end of the recovery phase, amphipods showed no significant preference between ungrazed and grazed pieces of the tested algae (Fig. 3, Table 1).

\section{DISCUSSION}

Herein, algae showed variable responses of defense against meso-herbivores (Table 2). The red alga Grateloupia doryphora did not react with defense in either of the two experiments. In contrast, the red alga Chondracanthus chamissoi and the brown alga Lessonia nigrescens responded inconsistently, but with a diminishing palatability after the EXPIN (for C. chamissoi and $L$. nigrescens) and AIR experiment (for $L$. nigrescens). Glossophora kunthii only responded in the AIR experiment, but therein showed a clear response of inducible defense. These observations indicate high plasticity in anti-herbivory responses of algae, which could be due to grazer- or algae-specific traits.

Variable responses of two brown and red algal species to different meso-grazers

Our results suggest grazer-specific antiherbivory responses in brown and red macroalgae. Both brown algae (L. nigrescens and G. kunthii) deterred amphipods but not sea urchins (Table 2). This suggests that the defensive reactions and the effectiveness of deterrents of both algae depend on the species of meso-herbivores used. Pavia \& Toth (2000) reported a similar pattern for the brown alga Ascophyllum nodosum, revealing that grazing by the gastropod Littorina obtusata can induce deterrents while grazing by the isopod Idotea granulosa had no effect on algal deterrents. In the kelp Ecklonia radiata, Steinberg (1995) demonstrated that grazing by sea urchins also did not induce elevated levels of deterrents. Possibly, algae do not react against all grazers indiscriminately with defensive reactions, because not all grazers affect the fitness and thus reproduction of algae. Indeed, G. kunthii showed inducible defensive plasticity only against one species of amphipod grazers (Parhyalella ruffoi), whereas L. nigrescens responded against two (Hyale hirtipalma and P. ruffoi). The varying responses of $G$. kunthii against tested grazers could be also due to temporal variations in algal deterrents as reported for other brown algae (Connan et al. 2004).

Also there is consistency in the defensive reactions of L. nigrescens after the EXPIN- and AIR-experiment (acclimation phase) with the results from another study (Rothäusler \& Thiel in press). In that study detached control plants lost their defensive capacity when maintained without the amphipod $P$. ruffoi while detached plants held with grazers maintained low palatability to meso-grazers. The same pattern was revealed in the present study at the end of the EXPIN experiment. Moreover after the acclimation phase in the AIR experiment the attached (and possibly grazed) plants from the field ('Natural' level) were always well defended in contrast to detached control plants that may lose their defensive capacities due to an effect of detachment and grazer absence (Rothäusler \& Thiel in press). This all suggests that L. nigrescens might generally deter peracarid meso-grazers. Apparently, this responsive reaction is not inducible but rather constitutive, which is consistent with the results from Martínez (1996) who found no inducible response in L. nigrescens after mechanical injury of blades from plants transplanted to shallow subtidal hard-bottoms. Similarly, Toth \& Pavia (2002) detected in an outdoorlaboratory experiment a lack of induction in the kelp Laminaria hyperborea.

The findings for $G$. kunthii (AIR experiment) are also consistent with those of Macaya et al. (2005) who reported inducible defense for $G$. kunthii in response to $P$. ruffoi attacks. In contrast, the two red algae tested in our study, showed missing ( $G$. doryphora) or highly variable grazer repulsive responses $(C$. chamissoi). Both experiments indicate that $G$. doryphora did not deter herbivores. Cetrulo \& Hay (2000) detected a similar pattern in the red alga Halymenia trigona, which belongs to the same family as $G$. doryphora, after grazing pressure by fish and sea urchin. Thus, it appears that $G$. doryphora (and possibly other algae from the family Halymeniaceae) exhibit no inducible defense. 
ACCLIMATION PHASE

INDUCTION PHASE

RECOVERY PHASE
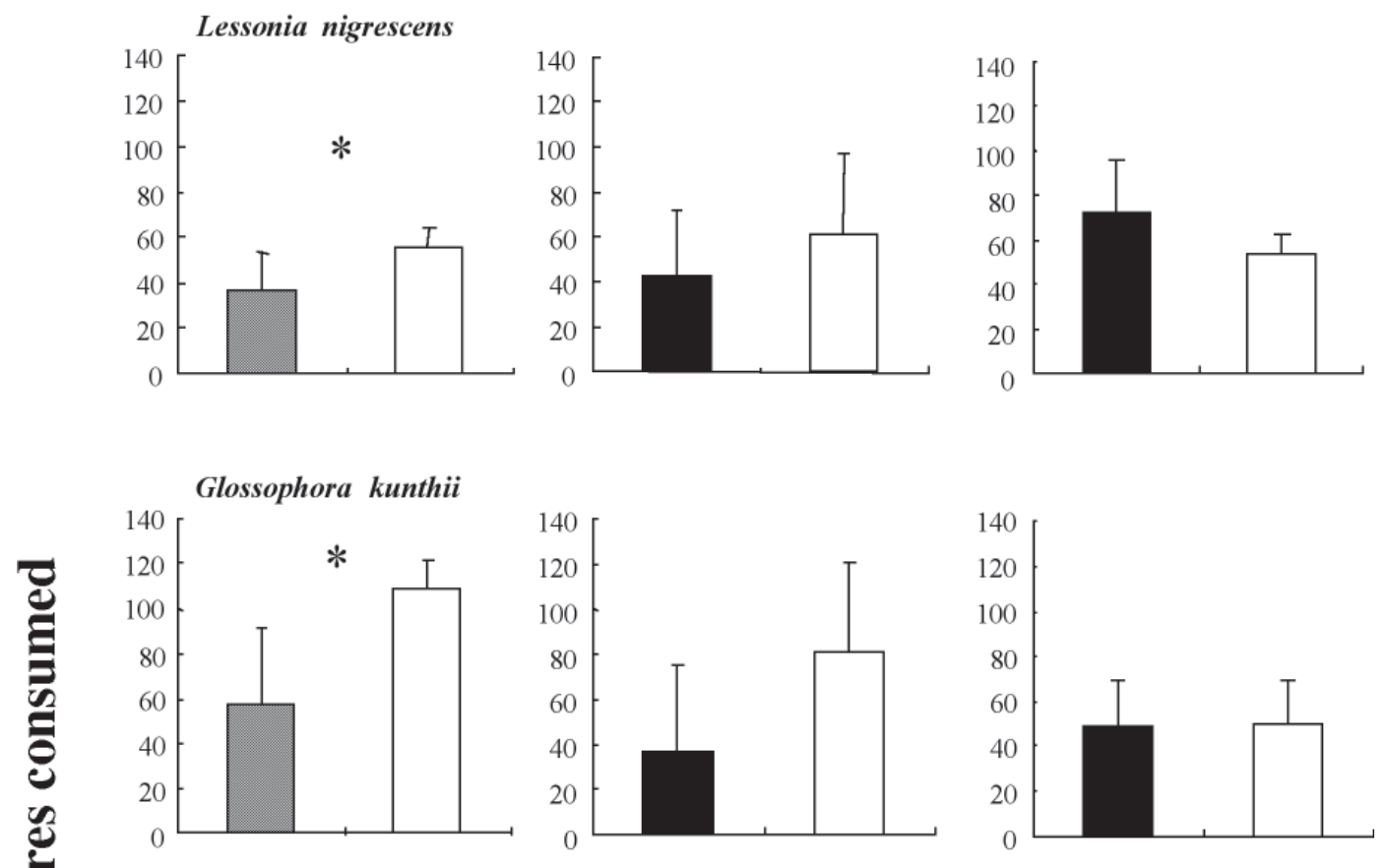

Grateloupia doryphora
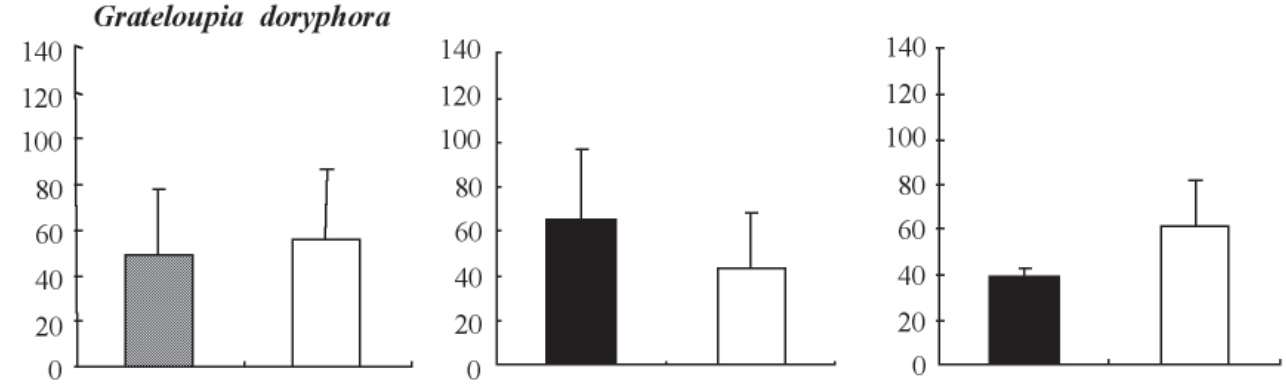

Chondracanthus chamissoi
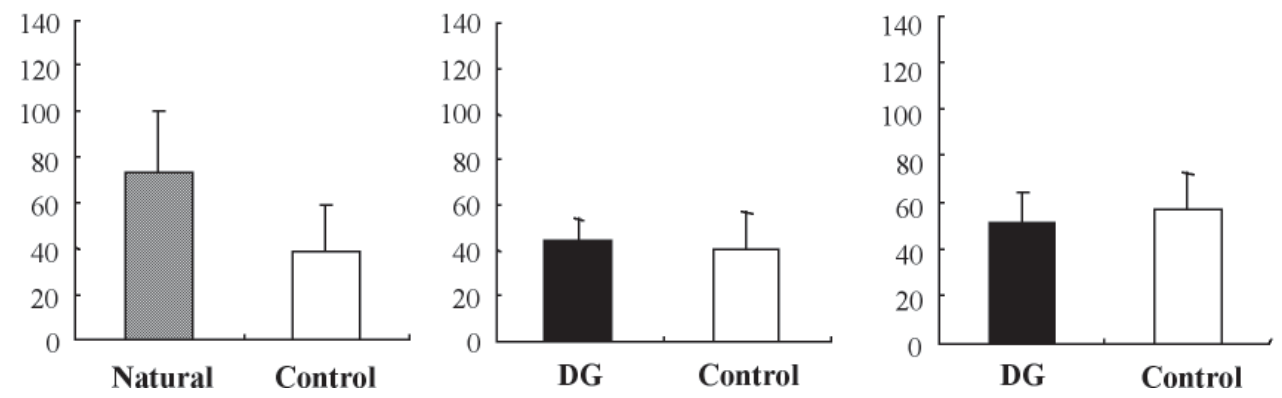

Fig. 2: Acclimation-induction-recovery AIR experiment: mean ( \pm SD) consumption (number of squares) of the amphipod Parhyalella ruffoi on agar-based food containing non-polar extracts of Lessonia nigrescens, Glossphora kunthii, Grateloupia doryphora and Chondracanthus chamissoi at the end of the acclimation, induction and recovery phase; $\mathrm{n}=5,\left(^{*}\right)=\mathrm{P}<0.05$.

Experimento de aclimatación-inducción-recuperación AIR: media ( \pm DE) del número de cuadrados consumidos del alimento artificial en base de agar en Lessonia nigrescens, Glossphora kunthii, Grateloupia doryphora y Chondracanthus chamissoi por Parhyalella ruffoi después de las fases de aclimatación, inducción y recuperación; $\mathrm{n}=5,(*)=\mathrm{P}<0,05$. 
INDUCTION PHASE
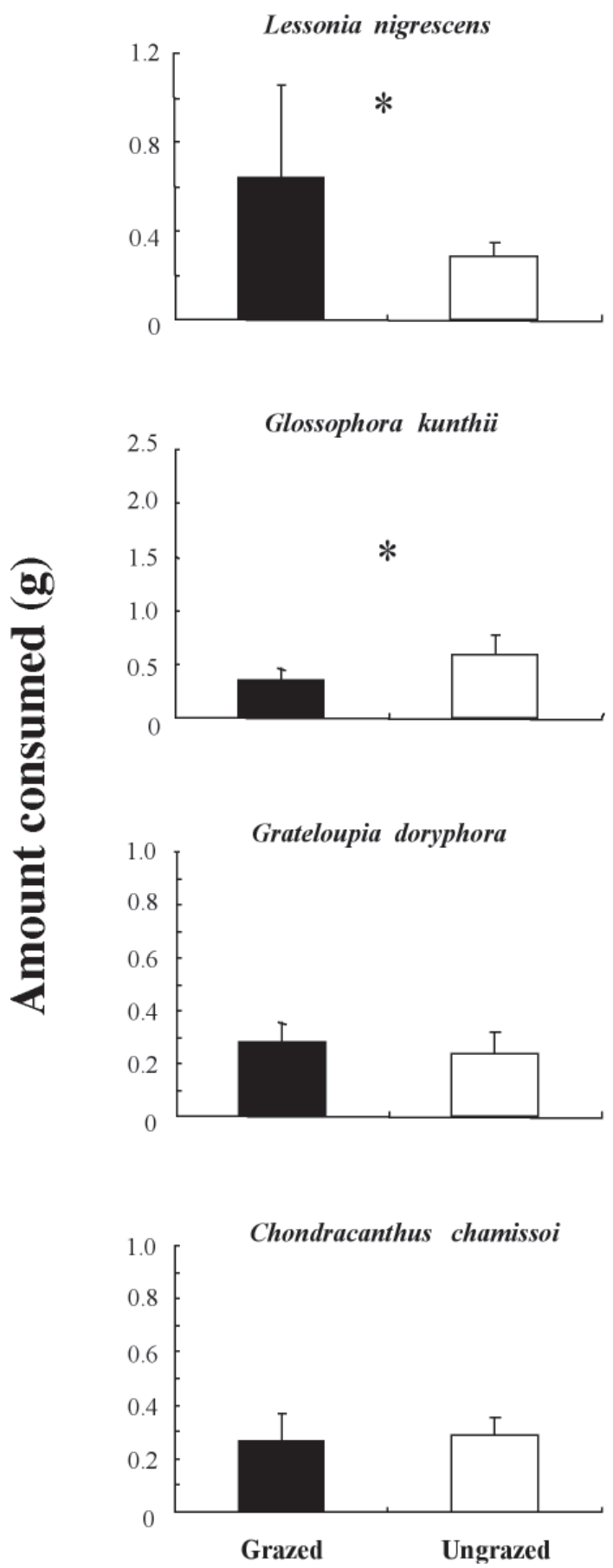

RECOVERY PHASE
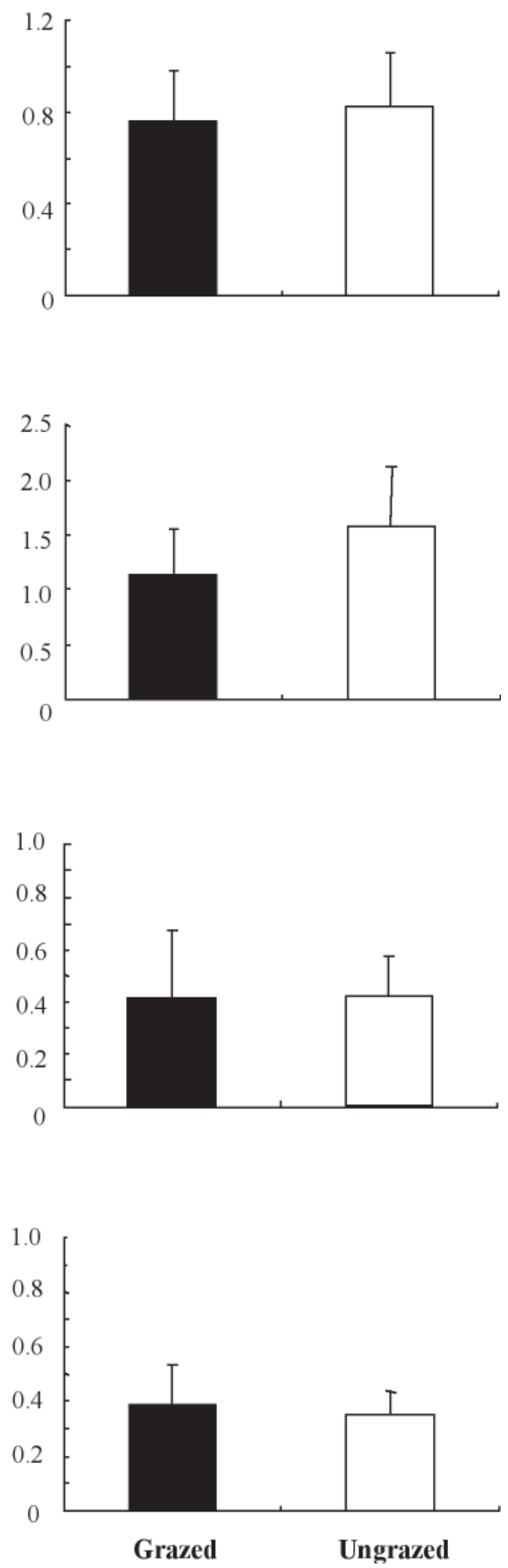

Fig. 3: Acclimation-Induction-Recovery AIR experiment: Mean ( \pm SD) consumption (g) of the amphipod Parhyalella ruffoi, on live individuals of Lessonia nigrescens, Glossophora kunthii, Grateloupia doryphora and Chondracanthus chamissoi at the end of the induction and recovery phase; $\mathrm{n}=5,(*)=\mathrm{P}<0.05$.

Experimento de aclimatación-inducción-recuperación AIR: media ( $\pm \mathrm{DS})$ del consumo ( $\mathrm{g}$ ) de Lessonia nigrescens, Glossophora kunthii, Grateloupia doryphora y Chondracanthus chamissoi por Parhyalella ruffoi después de las fases de inducción y recuperación; $\mathrm{n}=5,(*)=\mathrm{P}<0,05$. 
TABLE 1

Results from Student t-test for independent samples, comparing amphipod consumption of ungrazed and grazed pieces from no-choice feeding assays with Lessonia nigrescens, Glossophora kunthii, Grateloupia doryphora and Chondracanthus chamissoi. Artificial = agar-based food containing non-polar algal extracts, live $=$ intact algal pieces, subscript $=$ degrees of freedom, significant results in bold

Resultados de las pruebas t de Student para muestras independientes, comparando el consumo de los anfípodos entre trozos expuestos a herbivoría y trozos controles sin herbivoría en experimentos de no elección con Lessonia nigrescens, Glossophora kunthii, Grateloupia doryphora y Chondracanthus chamissoi. Artificial = alimento en base de agar con extractos algales no polares, live $=$ trozos de algas frescos, subíndices $=$ grados de libertad

\begin{tabular}{|c|c|c|c|c|c|c|c|c|}
\hline & \multicolumn{2}{|c|}{ Lessonia nigrescens } & \multicolumn{2}{|c|}{ Glossophora kunthii } & \multicolumn{2}{|c|}{ Grateloupia doryophora } & \multicolumn{2}{|c|}{ Chondracanthus chamissoi } \\
\hline & live & artificial & live & artificial & live & artificial & live & artificial \\
\hline & $\mathrm{t}_{4}(\mathrm{p})$ & $\mathrm{t}_{4}(\mathrm{p})$ & $\mathrm{t}_{4}(\mathrm{p})$ & $\mathrm{t}_{4}(\mathrm{p})$ & $\mathrm{t}_{4}(\mathrm{p})$ & $\mathrm{t}_{4}(\mathrm{p})$ & $\mathrm{t}_{4}(\mathrm{p})$ & $\mathrm{t}_{4}(\mathrm{p})$ \\
\hline $\begin{array}{l}\text { Acclimation } \\
\text { phase }\end{array}$ & & $-2.34(\mathbf{0 . 0 4 7 )}$ & & $-3.19(\mathbf{0 . 0 1 3})$ & & $-0.33(0.747)$ & & $-2.24(0.055)$ \\
\hline $\begin{array}{l}\text { Induction } \\
\text { phase }\end{array}$ & $-2.78(\mathbf{0 . 0 2 4})$ & $-0.90(0.393)$ & $-3.48(\mathbf{0 . 0 0 8})$ & $-1.18(0.112)$ & $-1.09(0.309)$ & $-1.19(0.270)$ & $-0.33(0.748)$ & $-0.51(0.624)$ \\
\hline $\begin{array}{l}\text { Recovery } \\
\text { phase }\end{array}$ & $-0.45(0.667)$ & $-1.52(0.166)$ & $-1.38(0.205)$ & $-0.09(0.933)$ & $-0.09(0.933)$ & $-2.35(0.079)$ & $-0.51(0.622)$ & $-0.66(0.526)$ \\
\hline
\end{tabular}

TABLE 2

Algal responses to exposure of different meso-grazers, at the end of the exploratory induction EXPIN and the acclimation-induction-recovery AIR experiment: "- " = no defense, "X" = defense, "+" = induced defense

Respuestas de las algas expuestas a diferentes meso-herbívoros generalistas, al final de los experimentos de inducción exploratorio EXPIN y experimento de aclimatación-inducción-recuperación AIR: "—" = sin respuestas defensivas, "X" = respuestas defensivas; "+” = respuestas defensivas inducibles

\begin{tabular}{|c|c|c|c|c|c|c|c|c|c|}
\hline \multicolumn{10}{|c|}{ Explorattory induction EXPIN experiment } \\
\hline \multicolumn{2}{|c|}{ Live algal pieces } & \multicolumn{2}{|c|}{ L. nigrescens } & \multicolumn{2}{|c|}{ G. kunthii } & \multicolumn{2}{|c|}{ G. doryophora } & \multicolumn{2}{|c|}{ C. chamissoi } \\
\hline & Hyale hirtipalma & \multicolumn{2}{|c|}{$\mathrm{X}$} & \multicolumn{2}{|c|}{ - } & \multicolumn{2}{|c|}{ - } & \multicolumn{2}{|c|}{$\mathrm{X}$} \\
\hline \multicolumn{4}{|c|}{ Isocladus bahamondei } & & & \multicolumn{2}{|c|}{ - } & \multicolumn{2}{|c|}{$\mathrm{X}$} \\
\hline \multicolumn{3}{|c|}{ Tetrapygus niger } & - & \multicolumn{2}{|c|}{-} & & & & \\
\hline & & & Accl & tizatic & nduction-F & overy & R experime & & \\
\hline \multirow{2}{*}{\multicolumn{2}{|c|}{ Whole live algae \& artificial food }} & \multicolumn{2}{|c|}{ L. nigrescens } & \multicolumn{2}{|c|}{ G. kunthii } & \multicolumn{2}{|c|}{ G. doryophora } & \multicolumn{2}{|c|}{ C. chamissoi } \\
\hline & & live & artificial & live & artificial & live & artificial & live & artificial \\
\hline $\begin{array}{l}\text { Acclimation } \\
\text { phase }\end{array}$ & & & $\mathrm{X}$ & & $\mathrm{X}$ & & - & & - \\
\hline $\begin{array}{l}\text { Induction } \\
\text { phase }\end{array}$ & Parhyalella ruffoi & - & - & + & - & - & - & - & - \\
\hline $\begin{array}{l}\text { Recovery } \\
\text { phase }\end{array}$ & & - & - & - & - & - & - & - & - \\
\hline
\end{tabular}


On the other hand, $C$. chamissoi deterred herbivores in the EXPIN, but not in the AIR experiment. Possibly grazing by the amphipod $P$. ruffoi had only a marginal impact on algal fitness and consequently the defensive response of $C$. chamissoi was not induced, but it is not well known whether this algal trait is inducible or not.

Outlook: varying anti-herbivore responses of macroalgae

In general, the patterns revealed herein showed a high degree of variability in algal responses suggesting that other factors besides grazing may affect the reaction of benthic macroalgae. The history of each individual alga may have caused the observed variability of responses, e.g. juvenile plants growing in habitats where grazer pressure is intense may react different to herbivores than conspecifics from habitats with low grazer pressure. For example, Van Alstyne (1988) revealed for natural populations of Fucus distichus that the concentrations of secondary metabolites was significantly higher in gastropod-grazed than in ungrazed algae. Another factor that may play a role in algal defense reaction is the geographic origin, because there is evidence that intensity of consumer activity is lower in temperate regions (Bolser \& Hay 1996). The ability of an alga to react to environmental changes might be higher in temperate as compared to relatively uniform tropical systems. Moreover, changes in extrinsic factors such as e.g. nutrients, light, UV-radiation and wave exposure influence the chemical composition of several macroalgae (Yates \& Peckol 1993, Cronin \& Hay 1996b, Martínez 1996, Peckol et al. 1996, Pavia \& Brock 2000). Variations in wave exposure can cause a heterogenic morphology in G. kunthii and L. nigrescens (see Malbrán \& Hoffmann 1990, Westermeier \& Gómez 1996, respectively). Similarly, the degree of wave exposure may modify herbivore pressure in the respective habitat and thus contributing to morphological shifts of algae and even to differences in deterrent compounds (see Martínez 1996 for L. nigrescens). Since all these factors cause a high variability within algal habitats, they may partly be responsible for the observed variability in anti-herbivore reactions revealed herein for macroalgae from
Chile. We propose future field studies testing the hypothesis that algae from different sites (with different grazing history) vary in their response to herbivore attacks.

\section{ACKNOWLEDGEMENTS}

We are grateful to the staff of the botany laboratory at Universidad Católica del Norte. Two anonymous reviewers provided many constructive comments on the manuscript. Funding was provided through the GAMEProject and FONDECYT 1010356.

\section{LITERATURE CITED}

AMSLER CD (2001) Induced defenses in macroalgae: the herbivore makes the difference. Journal of Phycology 37: 353-356.

BALDWIN IT (1998) Jasmonate-induced responses are costly but benefit plants under attack in native populations. Proceedings of the National Academy of Sciences USA, Physical Sciences 95: 8113-8118.

BOLSER RC \& ME HAY (1996) Are tropical plants better defended? Palatability and defenses of temperate vs. tropical seaweeds. Ecology 77: 2269-2286.

CARPENTER RC (1986) Partitioning herbivory and its effects on coral reef algal communities. Ecological Monographs 56: 345-363.

CETRULO G \& ME HAY (2000) Activated chemical defenses in tropical versus temperate seaweeds. Marine Ecology Progress Series 207: 243-253.

CLARK CW \& CD HARVELL (1992) Inducible defenses and the allocation of resources: a minimal model. American Naturalist 139: 521-539.

CONNAN S, F GOULARD, V STIGER, E DESLANDES \& EA GALL (2004) Interspecific and temporal variation in phlorotannin levels in an assemblage of brown algae. Botanica Marina 47: 410-416.

CRONIN G \& ME HAY (1996a) Induction of seaweed chemical defenses by amphipod grazing. Ecology 77: 2287-2301.

CRONIN G \& ME HAY (1996b) Effects of light and nutrient availability on the growth, secondary chemistry, and resistance to herbivory of two brown seaweeds. Oikos 77: 93-106.

DUFFY JE \& ME HAY (2001) The ecology and evolution of marine consumer-prey interactions. In: Bertness MD, ME Hay \& SD Gaines (eds) Marine Community Ecology: 131-157. Sinauer Associates, Sunderland, Massachusetts, USA.

HAY ME \& W FENICAL (1988) Marine plant-herbivore interactions: the ecology of chemical defense. Annual Review of Ecology and Systematics 19: 111-145.

HAY ME, JR PAWLIK, JE DUFFY \& W FENICAL (1989) Seaweed herbivore predator interactions: host plant specialization reduces predation on small herbivores. Oecologia 81: 418-427.

HAY ME \& PD STEINBERG (1992) The chemical ecology of plant-herbivore interactions in marine versus terrestrial communities. In: Rosenthal J \& M 
Berenbaum (eds) Herbivores: their interaction with secondary metabolites, evolutionary and ecological processes: 371-413. Academic Press, San Diego, California, USA.

HAY ME, QE KAPPEL \& W FENICAL (1994) Synergisms in plant defenses against herbivores: interactions of chemistry, calcification and plant quality. Ecology 75: 1714-1726.

HAY ME (1996) Marine chemical ecology: what is known and what is next? Journal of Experimental Marine Biology and Ecology 200: 103-134

HERMS DA \& WJ MATTSON (1992) The dilemma of plants to grow or defend. Quarterly Review of Biology 67: 283-335.

KARBAN R \& IT BALDWIN (1997) Induced responses to herbivory. University of Chicago Press, Chicago, Illinois, USA. 330 pp.

LUBCHENCO J \& SD GAINES (1981) A unified approach to marine plant-herbivore interactions: I. Populations and communities. Annual Review of Ecology and Systematics 12: 405-437.

MACAYA EC, E ROTHÄUSLER, M THIEL, M MOLIS \& M WAHL (2005) Induction of defenses and within-alga variation on palatability in two brown algae from the northern-central coast of Chile: effects of mesograzers and UV radiation. Journal of Experimental Marine Biology and Ecology 325: 214-227

MALBRÁN ME \& AJ HOFFMANN (1990) Seasonal cycles of growth and tetraspore formation in Glossophora kunthii (Phaeophyta, Dictyotales) from Pacific South America: field and laboratory studies. Botanica Marina 33: 219-223.

MARTÍNEZ EA (1996) Micropopulation differentiation in phenol content and susceptibility to herbivory in the Chilean kelp Lessonia nigrescens (Phaeophyta, Laminariales). Hydrobiologia 326/327: 205-211.

PAUL V J \& ME HAY (1986) Seaweed susceptibility to herbivory: chemical and morphological correlates. Marine Ecology Progress Series 33: 255-264.

PAUL VJ \& KL VAN ALSTYNE (1987) Chemical defense and chemical variation in some tropical Pacific species of Halimeda (Halimedaceae; Chlorophyta). Coral Reefs 6: 263-269.

PAUL VJ \& KL VAN ALSTYNE (1992). Activation of chemical defenses in the tropical green algae Halimeda spp. Journal of Experimental Marine Biology and Ecology 160: 191-203.

PAVIA H \& E BROCK (2000) Extrinsic factors influencing phlorotannin production in brown alga Ascophyllum nodosum. Marine Ecology Progress Series 193: 284-285.

PAVIA H \& GB TOTH (2000) Inducible chemical resistance to herbivory in the brown seaweed Ascophyllum nodosum. Ecology 81: 3212-3225.

PECKOL P, JM KRANE \& JL YATES (1996) Interactive effects of inducible defense and resource availability on phlorotannins in the North Atlantic brown alga Fucus vesiculosus. Marine Ecology Progress Series 138: 209-217.

ROHDE S, M MOLIS \& M WAHL (2004) Regulation of anti-herbivore defence by Fucus vesiculosus in response to various cues. Journal of Ecology 92: 1011-1018.

ROTHÄUSLER E \& M THIEL (in press) Effect of detachment on the palatability of two kelp species. Journal of Applied Phycology.

SOTKA E, RB TAYLOR \& ME HAY (2002) Tissuespecific induction of resistance to herbivores in a brown seaweed: the importance of direct grazing versus waterborne signals from grazed neighbors. Journal of Experimental Marine Biology and Ecology 277: 1-12.

STEINBERG PD (1995) Seasonal variation in the relationship between growth rate and phlorotannin production in the kelp Ecklonia radiata. Oecologia 102: 169-173.

TAYLOR RI, E SOTKA \& ME HAY (2002) Tissuespecific induction of herbivore resistance: seaweed response to amphipod grazing. Oecologia 132, 6876.

TOTH GB \& H PAVIA (2002) Lack of phlorotannin induction in the kelp Laminaria hyperborea in response to grazing by two gastropod herbivores. Marine Biology 140: 403-409.

UNDERWOOD AJ (1997) Experiments in ecology: their logical design and interpretation using analysis of variance. Cambridge University Press, Cambridge, United Kingdom. 504 pp.

VAN ALSTYNE KL (1988) Herbivore grazing increases polyphenolic defenses in the intertidal brown alga Fucus distichus. Ecology 69: 655-663.

VAN ALSTYNE KL (1989) Adventitious branching as a herbivore-induced defense in the intertidal brown alga Fucus distichus. Marine Ecology Progress Series 56: 169-176.

WATSON D \& TA NORTON (1985) The physical characteristics of seaweed thalli as deterrents to littorine grazers. Botanica Marina 28: 383-387.

WEIDNER K, BG LAGES, BAP DA GAMA, M MOLIS, M WAHL \& RC PEREIRA (2004) Effect of mesograzers and nutrient levels on induction of defenses in several Brazilian macroalgae. Marine Ecology Progress Series 283: 113-125.

WESTERMEIER R \& I GÓMEZ (1996) Biomass, energy content and major organic compounds in the brown alga Lessonia nigrescens (Laminariales, Phaeophyceae) from Mehuín, south Chile. Botanica Marina 39: 553-5

YATES JL \& P PECKOL (1993) Effects of nutrient availability and herbivory on polyphenolics in the seaweed Fucus vesiculosus. Ecology 74: 1757-1766. 